\section{Accidents at work and living conditions among solid waste segregators in the open dump of Distrito Federal}

\section{Acidentes de trabalho e condições de vida de catadores de resíduos sólidos recicláveis no lixão do Distrito Federal}

\section{Maria da Graça Hoefel'}

Fernando Ferreira Carneiro'

Leonor Maria Pacheco Santos'

Muriel Bauerman Gubert"

Elisa Maria Amate"'I

Wallace dos Santos ${ }^{\text {IV }}$

'Department of Public Health, Universidade de Brasília - Brasília (DF), Brazil.

"Department of Nutrition, Universidade de Brasília - Brasília (DF), Brazil.

"'Master's Degree in Collective Health, Universidade de Brasília - Brasília (DF), Brazil.

Iv Master's Degree in Health Sciences, Universidade de Brasília - Brasília (DF), Brazil.

\section{Abstract}

The work of recycling solid waste segregators allows a precarious livelihood, but triggers a disease process that exacerbates their health and well-being. This study aimed to estimate the prevalence of occupational accidents at the open dump in the Federal District and its associated factors. Most segregators have had an accident at work (55.5\%), perceived the danger of their working environment (95.0\%) and claimed they did not receive personal protective equipment (51.7\%). Among other findings, $55.8 \%$ ate foods found in the trash, $50.0 \%$ experienced food insecurity at home and $44.8 \%$ received Bolsa Família. There was a statistically significant relationship between work accidents and perception of dangerous work environment, household food insecurity and the presence of fatigue, stress or sadness ( $\mathrm{p}<0.05$ ). On the other hand, the fellowship between the segregators was associated with a lower prevalence of accidents $(\mathrm{p}<0.006)$. Women are the majority of the segregators (56.5\%) and reported more accidents than men $(\mathrm{p}<0.025)$. We conclude that the solid waste segregators constitute a vulnerable community, not only from the perspective of labor, but also from the social and environmental circumstances. To reverse this situation, effective implementation of the National Policy of Solid Wastes is imperative, in association with affirmative policies to grant economic emancipation for this population.

Keywords: Occupational health. Solid waste. Open dumps. Solid waste segregators. Accidents, Occupational. Environmental exposure. National Policy of Solid Wastes. 


\section{Resumo}

O trabalho de catadores de resíduos sólidos recicláveis gera um precário sustento, porém desencadeia processos de adoecimento que agravam sua condição de vida. Objetivou-se estimar a prevalência de acidentes de trabalho no lixão do Distrito Federal e fatores associados. Observou-se que a maioria dos catadores já se acidentou no trabalho $(55,5 \%)$, tem noção da periculosidade do ambiente de trabalho $(95,0 \%)$ e alega não receber equipamento de proteção individual $(51,7 \%)$. Dentre outros achados, 55,8\% já comeu alimentos encontrados no lixo, 50,0\% vivenciava insegurança alimentar em seus domicílios e $44,8 \%$ recebia Bolsa Família. Constatou-se relação estatisticamente significativa entre acidentes de trabalho e percepção de trabalho perigoso, alegação de cansaço, estresse ou tristeza e insegurança alimentar $(\mathrm{p}<0,05)$. Por outro lado a percepção de companheirismo entre os catadores esteve associada à menor prevalência de acidentes $(\mathrm{p}<0,006)$. As mulheres são a maioria dos catadores $(56,5 \%)$ e se acidentam mais que os homens ( $\mathrm{p}<0,025)$. Conclui-se que esta comunidade de catadores apresenta alta vulnerabilidade, não somente pela ótica da saúde do trabalhador, mas também pelas questões socioambientais envolvidas. Para a reversão desse quadro torna-se imperativa a efetiva implantação da Política Nacional de Resíduos Sólidos, associada a políticas de inclusão social e de emancipação econômica dessa população.

Palavras-chave: Saúde do trabalhador. Resíduos sólidos. Lixões. Catadores. Acidentes de trabalho. Exposição ambiental. Política Nacional de Resíduos Sólidos.

\section{Introduction}

The consumption model adopted by contemporary society leads to the depletion of natural resources, increased poverty and imbalance, because it is founded on accumulation and waste ${ }^{1}$. According to Porto ${ }^{2}$, that's where the expression "disposable" comes from. It is now practiced without much control, triggering two things: one, the quality and quantity of waste generated and, two, in the face of economic and social policies, an excluded mass, which "benefits" from this income generation - the recyclable material segregators. By collecting and separating recyclable materials - be it from open dumps, from "controlled landfills," or even from recycling plants throughout the country - the segregator is an important link in the recycling system ${ }^{3}$. Brazilian Law no. 12,305 of August 2, 2010, established the PNRS, the National Policy on Solid Waste, whose goal, among others, is the elimination of open dumps by 2014 , associated with the social inclusion and economic empowerment of reusable and recyclable materials segregators ${ }^{4}$. According to the National Basic Sanitation Survey ${ }^{5}$ conducted in 2008, it was identified that there were still 2,906 open dumps in Brazil, spread over 2,810 municipalities. In absolute numbers, the State of Bahia had the most municipalities with open dumps (360), followed by Piauí (218), Minas Gerais (217) and Maranhão (207). Other relevant information is that $98 \%$ of existing open dumps were concentrated in small towns and $57 \%$ were in the northeast.

According to Siqueira ${ }^{3}$, it is common that waste collection from open dumps is able to provide segregators with a precarious livelihood, but it will certainly bring diseases to and worsen the living conditions of this population. Some studies have pointed out the living and working conditions of this group ${ }^{6-8}$. In a study conducted in Porto Alegre ${ }^{8}, 61 \%$ of the segregators stated they realized the impact that pollution has on health. In the same sense, there was a high rate of withdrawals from segregators in Governador Valadares, Minas Gerais, due to 
health problems, causing a deficit of workers ${ }^{9}$. Among the working conditions, we found an increase in these workers' exposure to risks of diseases and accidents at work.

Existing laws ${ }^{10,11}$, define workplace accident as a sudden event that occurs in the exercise of work activity, regardless of the employment situation, and which leads to health damage, potential and immediate, causing bodily injury or functional disorder that causes, directly or indirectly, death, or the loss or reduction, permanent or temporary, of the ability to work ${ }^{11}$. The economic and social losses of such accidents need to be further investigated, as well as the development of chronic sequelae and late onset from events recognized as occupational accidents in open dumps ${ }^{12}$.

Accidents in this type of environment usually happen due to precariousness and lack of appropriate working conditions, translated in injury and loss of members by trampling and compressing in compression equipment and motor vehicles, besides animal bites (dogs, rats) and bug bites ${ }^{13}$.

Literature shows that segregators are in a community of risk ${ }^{9}$ and there are few studies that relate these risks to public health to this activity ${ }^{3,14}$. In a more ad hoc approach to the subject, specifically with a focus on the worker, many studies list accidents with cuts, punctures, burns and dermatitis as consequences of that relationship, in addition to the high incidence of food poisoning and parasitic diseases ${ }^{15,16}$. Considering the social, environmental and sanitary vulnerability of the aforementioned population of workers, this study estimated the prevalence of health aggravations to recyclable solid waste segregators in the Estrutural open dump, aiming particularly to reveal the problems related to environmental, working and health conditions of this population, contributing to the implementation of public policies to address this issue.

\section{Material and Methods}

The study area is located in the Federal District, in the vicinity of the Brasilia National
Park(BNP), about 20 miles from the Presidential Palace, and is approximately 147 ha (429.963 acres) in area ${ }^{17}$. It was named "Estrutural open dump" because of its proximity to the DF-095, known as Estrutural - a connecting road between the Pilot Plan and the administrative regions, Taguatinga and Ceilândia. The open dump was created more than 50 years ago, along with the construction of Brasília, and for decades there has been the promise of its deactivation ${ }^{18}$. There are 45,000 people living in its surroundings, and $15 \%$ of them survive on the collection of recyclable solid waste on the site ${ }^{17}$.

A census of the families of recyclable materials segregators who live in five blocks in the region, Região Administrativa XXV - Setor Complementar de Indústria e Abastecimento (SCIA), known as Vila Estrutural, in the Federal District, revealed 204 households and 835 residents. In these households, one segregator was selected to report on working conditions - generally, the head of the family. In four cases, the information on accidents at work has not been obtained, totaling in a sample of 200 segregators. A pre-tested form was used, containing questions about socio-demographic status, social programs, housing conditions, basic sanitation, work and the environment. Food security was assessed from the short scale, with six questions, now a standard in Brazil. The respondent was the head of the family or the person responsible for food acquisition, as requested by the method ${ }^{19}$.

Technicians from the Department of Health, State Department of Social Development and Income Transfer, State Department of Health, Child Protection Council, block mayors and community leaders were involved in the articulation for data collection, which occurred in November and December, 2011. All families with segregators living within the study area were invited to participate during the visit, which was notified to the community through partner organizations that were involved.

Fifteen teams, consisting of two interviewers and one Community Health Agent collected the data from homes, only on 
Sundays, which is the segregators' only day off. The interviewers, undergraduates in Management in Public Health and Nutrition at Universidade de Brasília (UnB), participated in the project design team and in the pre-test of the form. At the end of each collection day, the teams verified if the questions have been adequately completed. The remaining information quality control steps occurred at the time of data typing and analysis.

For data analysis, SPSS software, version 19.0, was used. An univariate analysis was conducted to express the frequency of dependent (accident at work) and explanatory variables, while measures of associations were tested using Pearson's chi-squared test and the Mantel-Haenszel test for trends, as appropriate, adopting the $\mathrm{p}<0.05$. As independent variables, those that could potentially act as risk factors for accidents were selected, among which gender, age, fatigue, stress and sadness, and work environment were considered dangerous, apart from other risks such as competition, food insecurity and hunger, access and use of Personal Protective Equipment (PPE).

According to the terms of Resolution no. 196, of October 10,1996, by the National Health Council, this research took into account ethical principles and was approved by the UnB Research Ethics Committee, under protocol 151/2011. The participants were informed about the research and expressed consent of participation by signing an informed consent.

The consolidated results were returned to the community in a meeting of the Social Network of Estrutural in February 2012, with the participation of experts from the government and community leaders. The presentation was recorded by the Estrutural City Social Monitoring Forum ${ }^{20}$. Another community meeting was organized at the headquarters of the NGO "Coletivo da Cidade" to present the results to the presidents of recycling cooperatives in August 2012.

\section{Results}

Tablel describes the working conditions and some characteristics of the segregators who composed the study. The predominance is of female segregators, and $85 \%$ of these workers are in reproductive age until 49 years of age. Most of them are aware of the danger of their work environment, which $95 \%$ of workers rated as "dangerous" or "very dangerous." Among the respondents, the occurrence of accidents was $55 \%$, which corroborates this observation. The relationship with other collectors was described generally as of companionship. Over $79.2 \%$ of workers reported being stressed, sad or tired towards work and most considered unfair income from their work. The urban cleaning company stated in several interviews that they distributed PPE, but $51.7 \%$ of the segregators said they have not received them. In contrast, $10.4 \%$ of workers reported not using PPE; those who use the equipment obtained them through donations, purchased them or found them scavenging the trash.

The data in Table 2 show that $66 \%$ of the segregators, who are heads of households, were born in other Brazilian regions, particularly the northeast. More than half of the families were headed by women (54.0\%). On average, segregators started this activity at 13.8 years of age, and they have been working on this for an average of ten years (Table 3 ).

Picking up food from the trash to eat was reported by $55.8 \%$ of segregators, and food insecurity was detected in $50.0 \%$ of households. Social protection in the form of income transfers (Bolsa Família) reached less than a half of the families investigated. In the largest share of the 200 households included in the study, there was access to piped water and electricity, but only $64 \%$ of them were connected to the sewage network. The presence of rats and cockroaches was declared in $89.8 \%$ of households (Table 2).

Table 4 shows a higher risk of accidents among women, as well as the relevance to the number of accidents when the segregator considers the work very dangerous. It shows that the greater the perception of an existing fellowship among segregators, the fewer are the accidents that occur. Similarly, the existence of a statistically significant relationship 
between fatigue/stress/sadness and food insecurity and accidents at work was verified. Other data showed no relationship with the variable in question $(\mathrm{p}>0.05)$.
Accidents were reported more frequently among segregators who claimed to use some type of PPE. However, the difference did not reach statistical significance.

Table 1 - Working conditions and demographic description of solid waste segregators in Distrito Federal, 2011.

Tabela 1 - Condições de trabalho e características demográficas de catadores de materiais recicláveis residentes no Distrito Federal, 2011.

\begin{tabular}{|c|c|c|}
\hline Working conditions and demographic description & $\mathrm{n}$ & $\%$ \\
\hline \multicolumn{3}{|l|}{ Gender $(n=200)$} \\
\hline Male & 87 & 43.5 \\
\hline Female & 113 & 56.5 \\
\hline \multicolumn{3}{|l|}{ Age group - both genders $(n=200)$} \\
\hline Up to 20 years & 69 & 34.5 \\
\hline 30 to 39 years & 67 & 33.5 \\
\hline 40 to 49 years & 35 & 17.5 \\
\hline 50 to 74 years & 29 & 14.5 \\
\hline \multicolumn{3}{|l|}{ Age group - women $(n=113)$} \\
\hline Up to 20 years & 31 & 27.4 \\
\hline 30 to 39 years & 44 & 38.9 \\
\hline 40 to 49 years & 21 & 18.6 \\
\hline 50 to 74 years & 17 & 15.0 \\
\hline \multicolumn{3}{|l|}{ Considered work as a segregator $(n=200)$} \\
\hline Very dangerous & 118 & 59.0 \\
\hline Dangerous & 72 & 36.0 \\
\hline Safe & 10 & 5.0 \\
\hline \multicolumn{3}{|l|}{ Type of working relationship with other segregators $(n=197)$} \\
\hline Fellowship & 128 & 65.0 \\
\hline Competitiveness & 45 & 22.8 \\
\hline Indifference & 24 & 12.2 \\
\hline Reported tiredness, stress, sadness about their work $(n=197)$ & 156 & 79.2 \\
\hline Did not consider their work important to society $(n=197)$ & 31 & 15.7 \\
\hline Thought the income from their work was unfair $(n=199)$ & 129 & 64.8 \\
\hline Reported having eaten food collected from trash $(n=199)$ & 111 & 55.8 \\
\hline Presented some kind of disease at the time $(n=200)$ & 64 & 32.0 \\
\hline Presented diarrhea in the last three months $(n=194)$ & 42 & 21.6 \\
\hline Did not receive Personal Protection Equipment (PPE) $(n=180)$ & 93 & 51.7 \\
\hline Did not use Personal Protection Equipment (PPE) $(n=193)$ & 20 & 10.4 \\
\hline Had experienced an accident at work at some point $(n=200)$ & 111 & 55.5 \\
\hline
\end{tabular}


Table 2 - Household conditions and socio-demographic characteristics among families of solid waste segregators in Distrito Federal, 2011.

Tabela 2 - Condições dos domicílios e características sociodemográficas das famílias de catadores de materiais recicláveis residentes no Distrito Federal, 2011.

\begin{tabular}{|c|c|c|}
\hline Household conditions and family characteristics & $\mathrm{n}$ & $\%$ \\
\hline \multicolumn{3}{|l|}{ Birthplace of head of household $(n=200)$} \\
\hline North & 3 & 1.5 \\
\hline Northeast & 97 & 48.5 \\
\hline Midwest & 68 & 34.0 \\
\hline Southeast & 32 & 16.0 \\
\hline \multicolumn{3}{|l|}{ Gender of head of household $(n=200)$} \\
\hline Male & 92 & 46.0 \\
\hline Female & 108 & 54.0 \\
\hline Household presented food insecurity $(n=196)$ & 98 & 50.0 \\
\hline Family member has had any disease caused by contaminated trash, water or food ( $n=178$ ) & 63 & 35.4 \\
\hline Family member was a Bolsa Família beneficiary $(n=200)$ & 87 & 44.8 \\
\hline \multicolumn{3}{|l|}{ Monthly family income (in minimum wage) ( $n=192$ ) } \\
\hline Less than half the minimum wage $(\mathrm{R} \$ 272)$ & 10 & 5.2 \\
\hline Half to one minimum wage ( $R \$ 273$ a $R \$ 544)$ & 67 & 34.9 \\
\hline One to double the minimum wage ( $R \$ 545$ a $R \$ 1.090)$ & 93 & 48.4 \\
\hline More than double the minimum wage ( $\mathrm{R} \$ 1.090)$ & 22 & 11.5 \\
\hline \multicolumn{3}{|l|}{ Monthly expenditure on food (in minimum wage) $(n=186)$} \\
\hline Less than half the minimum wage $(\mathrm{R} \$ 272)$ & 76 & 40.9 \\
\hline Half to one minimum wage ( $R \$ 273$ a $R \$ 544)$ & 81 & 43.5 \\
\hline One to double the minimum wage ( $\mathrm{R} \$ 545$ a $\mathrm{R} \$ 1.090)$ & 29 & 15.6 \\
\hline \multicolumn{3}{|l|}{ Building material on the walls $(n=198)$} \\
\hline Brickwork & 91 & 46.0 \\
\hline Wood or others & 107 & 54.0 \\
\hline \multicolumn{3}{|l|}{ Building material on the floor $(n=195)$} \\
\hline Ceramic/cement & 145 & 74.4 \\
\hline Earthen floor & 50 & 25.6 \\
\hline Access to piped water $(n=200)$ & 186 & 93.0 \\
\hline Treated the water for consumption in some way $(n=197)$ & 115 & 58.4 \\
\hline Access to sewerage $(n=200)$ & 128 & 64.0 \\
\hline Access to electricity $(n=200)$ & 196 & 98.0 \\
\hline Presence of rats and cockroaches in the home $(n=197)$ & 177 & 89.8 \\
\hline
\end{tabular}

$\mathrm{SM}$ : minimum wage.

SM: salário mínimo.

Table 3 - Average for selected socio-demographic characteristics among solid waste segregators in Distrito Federal, 2011. Tabela 3 - Médias para características sociodemográficas selecionadas de catadores de materiais recicláveis residentes no Distrito Federal, 2011.

\begin{tabular}{lc}
\hline Characteristic & Mean \pm Standard deviation \\
\hline Age when started work as segregator (years) $(n=198)$ & $13.8 \pm 6.7$ \\
Time of work as segregator $(n=199)$ & $10.3 \pm 7.1$ \\
Time of residence in Estrutural $(n=200)$ & $13.3 \pm 7.0$ \\
Number of members per household $(n=200)$ & $4.6 \pm 2.5$ \\
Household income $(R \$)(n=192)$ & $704 \pm 429$ \\
Monthly expenditure on food $(R \$)(n=186)$ & $348 \pm 206$ \\
\hline
\end{tabular}


Table 4 - Occurrence of occupational accidents according to selected characteristics among solid waste segregators in Distrito Federal, 2011.

Tabela 4 - Ocorrência de acidente de trabalho segundo características selecionadas entre catadores de materiais recicláveis residentes no Distrito Federal, 2011.

\begin{tabular}{|c|c|c|c|}
\hline \multirow{2}{*}{ Associated factors } & \multicolumn{2}{|c|}{ Accident prevalence } & \multirow{2}{*}{$\mathrm{p}$-value } \\
\hline & $\mathrm{n}$ & $\%$ & \\
\hline \multicolumn{4}{|l|}{ Gender of segregator } \\
\hline Male & 40 & 46.0 & \multirow{2}{*}{0.025} \\
\hline Female & 71 & 62.8 & \\
\hline \multicolumn{4}{|l|}{ Age group } \\
\hline$<30$ years & 42 & 57.5 & \multirow{4}{*}{ NS } \\
\hline 31 to 40 years & 40 & 61.5 & \\
\hline 41 to 50 years & 19 & 52.8 & \\
\hline 51 to 74 years & 10 & 38.5 & \\
\hline \multicolumn{4}{|l|}{ Considered work as segregator } \\
\hline Very dangerous & 78 & 66.1 & \multirow{3}{*}{0.001} \\
\hline Dangerous & 30 & 41.7 & \\
\hline Safe & 3 & 30.0 & \\
\hline \multicolumn{4}{|l|}{ Type of working relationship with other segregators } \\
\hline Fellowship & 62 & 48.4 & \multirow{3}{*}{0.006} \\
\hline Competitiveness & 34 & 75.6 & \\
\hline Indifference & 12 & 50.0 & \\
\hline \multicolumn{4}{|l|}{ Reported tiredness, stress, sadness about work } \\
\hline Yes & 93 & 59.6 & \multirow{2}{*}{0.008} \\
\hline No & 15 & 36.6 & \\
\hline \multicolumn{4}{|l|}{ Considered work important to society } \\
\hline Yes & 98 & 59.0 & \multirow{2}{*}{0.015} \\
\hline No & 11 & 35.5 & \\
\hline \multicolumn{4}{|l|}{ Considered income from work fair } \\
\hline Yes & 34 & 48.6 & \multirow[b]{2}{*}{ NS } \\
\hline No & 76 & 58.9 & \\
\hline \multicolumn{4}{|l|}{ Reported having eaten food from trash } \\
\hline Yes & 68 & 61.3 & \multirow{2}{*}{ NS } \\
\hline No & 43 & 48.9 & \\
\hline \multicolumn{4}{|l|}{ Presented any kind of disease at the time } \\
\hline Yes & 35 & 54.7 & \multirow{2}{*}{ NS } \\
\hline No & 76 & 55.9 & \\
\hline \multicolumn{4}{|l|}{ Received Personal Protection Equipment } \\
\hline Yes & 49 & 56.3 & \\
\hline No & 55 & 59.1 & NS \\
\hline Used Personal Protection Equipment & & & \\
\hline Yes & 95 & 54.9 & \\
\hline No & 9 & 45.0 & NS \\
\hline Food security in the household & & & \\
\hline Food security & 46 & 46.9 & \\
\hline Food insecurity & 61 & 62.2 & 0.031 \\
\hline Family monthly income (in minimal wage) & & & \\
\hline Less than half the minimum wage ( $\mathrm{R} \$ 272$ ) & 7 & 70.0 & \\
\hline Half to one minimum wage ( $R \$ 273$ a $R \$ 544)$ & 37 & 55.2 & \\
\hline One to double the minimum wage ( $R \$ 545$ a $R \$ 1.090)$ & 49 & 52.7 & NS \\
\hline More than double the minimum wage (R\$1.090) & 14 & 63.6 & \\
\hline Monthly expenditure on food (in minimum wage) ( $n=186$ & & & \\
\hline Less than half the minimum wage ( $\mathrm{R} \$ 272)$ & 42 & 55.3 & \\
\hline Half to one minimum wage ( $R \$ 273$ a $R \$ 544)$ & 41 & 50.6 & NS \\
\hline One to double the minimum wage ( $R \$ 545$ a $R \$ 1.090)$ & 20 & 69.0 & \\
\hline
\end{tabular}




\section{Discussion}

Child labor is prohibited in the Brazilian legal system, both in the Federal Constitution, Consolidation of Labor Laws, and in the Statute of Children and Adolescents, allowing only apprenticeships ${ }^{21,22}$. According to PNAD, (Pesquisa Nacional por Amostra de Domicílios, or The National Survey by Household Sampling $)^{23}$, in Brazil, approximately 4.2 million children and adolescents between 5 and 17 work. There is no official data on the work of children and adolescents in open dumps. It is noteworthy that, in this study, segregators started working in this activity, on average, at 13.8 years of age. Considering the high standard deviation (6.7 years), there was, in fact, a very early history of child labor. Child labor in open dumps is included in the list of the Worst Forms of Child Labour ${ }^{24}$, where it is stated that garbage collection is an extremely unhealthy activity, which causes serious damages to the health and development of children and adolescents.

Working conditions and occupational risks present in open dumps can clarify the complaints mentioned. Besides chemical hazards found in the dump, there are biological, physical and ergonomic hazards.

In an association of segregators of Divinópolis, Minas Gerais ${ }^{24}$, the work risks, including the ergonomic ones, are characterized by intense physical exertion, manual lifting of heavy loads, inadequate postures, excessive pace of work, work in a standing position, and physical and mental stress. Adding to this, there is the existence of night work, another factor that leads to stress and fatigue. The social relations in work that are considered important are crucial in the health/illness/work processes. Observe that, in this study, the greater the perception of an existing fellowship among segregators, the fewer the accidents.

This study showed a high prevalence of accidents at work in recyclable waste segregators at open dumps. The accidents occurred more frequently among women. A large number of women were observed in the study population, both as heads of the households and as part of the workforce. These are young women at the peak of their reproductive lives, whether or not in stable unions. The fact exacerbates the health risks, for the potential exposure to environmental contamination in the embryonic period in pregnancies.

A statistically significant relationship between accidents and perception of hazardous work was verified, with a doseresponse effect. In a study conducted in 2010 with the same population ${ }^{18}$, it was observed that only $35 \%$ of segregators already had accidents at work. On the other hand, studies confirm that most of these workers have had accidents at some point in their work collecting waste ${ }^{14}$. One possible explanation for this high prevalence would be the unhealthy environment and lack of safe conditions at work ${ }^{25}$. One fact, apparently contradictory, is the higher prevalence of accidents among those who consider their work important to society (Table 4 ). What kind of concrete situation could explain this higher prevalence? This points to the need for conducting qualitative studies that generate analyses and contribute to the exploration of issues like these. Thus, the occurrence of accidents may be related to the type of material found in the trash, especially those that puncture the skin, such as broken glass, needles and blades ${ }^{13}$. Moreover, lack of attention; fights; misuse of equipment; trampling; crushing; scare due to animals such as rats, scorpions, snakes and others ${ }^{25}$; hassles with personal problems or work and colleagues can result in accidents ${ }^{9}$.

Regarding the use of PPE, in Governador Valadares ${ }^{9}$, all segregators have access to it, but only a minority (14.6\%) uses PPE. In the present study, a majority makes use of PPE they find in the garbage, because they claim they do not receive the material. This is noteworthy data, once it contrasts with the literature of the studies surveyed here, for the participating workers did not receive the equipment, but they use their creativity to develop mechanisms to protect their health, emphasizing the notion of risk 
awareness and the need for safety at work. In Santo André, segregators of two cooperatives have PPE, but according to reports from the two chairmen of the cooperatives, they have to scold the workers and push them into using $\mathrm{it}^{26}$. Refusing to use PPE in spite of having access to it might be linked to the discomfort in its use during the workday ${ }^{27}$, considering the exhausting labor under various climatic conditions.

In the study presented here, accidents at work were reported more frequently among segregators who claimed to use some type of PPE, although the difference did not reach statistical significance. One possible explanation lies in the quality of equipment used by collectors, since a majority reported picking their "protection" directly from trash. Another possibility may be low adherence by workers to PPE, represented by the incorrect use of this resource, as well as the discomfort caused by their use. In the interviews conducted during field work, workers stated that the gloves "hinder" their movements when tearing the trash bags open. Even though the equipment does not solve the problem of the context of job insecurity, it can provide benefits that outweigh the harm and, through proper use, can contribute to worker safety ${ }^{28}$.

The perception of danger in the workplace is explained by $95 \%$ of respondents. That corroborates the accounts of segregators in Fortaleza, Ceará ${ }^{7}$, where no respondent denied that the work they were doing was unhealthy, painful, heavy or involved certain dangers and risks of illness, but were still working in spite of these characteristics, the discomforts, the malaises and the pains they felt, sometimes even minimizing problems. That is, in spite of this perception, they kept on working. According to Almeida $^{9}$, that could be associated with the lack of choice of work; therefore, it becomes an alternative source of income that allows the survival of many socially excluded people who survive on segregating recyclable materials. Adding to this, the daily experience with pollution makes people believe that the risks associated with it are natural ${ }^{8}$.
With respect to living conditions, it was observed that most segregators consumed food found in the garbage, and that half of the households were food insecure. Researches ${ }^{17,19}$ corroborate with this finding: the population collected food found in the garbage for their own consumption. Alexandrino ${ }^{6}$ points to the risk in this population's dietary habits, that of consuming food scraps, characterized by the contamination of segregators or residents near open dumps due to animals that are attracted to this space and feed on the waste in natura, disputing it with humans, in addition to other factors that affect the types of contaminants in the environment. Lack of knowledge regarding the risk of food poisoning, caused by microbial colonization, is observed ${ }^{24}$. The relationship between accidents and food insecurity raises the hypothesis that segregators in a low socioeconomic status, whose families are starving, take more risks in pursuit of survival, suggesting the need for further studies on this issue.

The Bolsa Família Program (PBF) is a conditional income transfer program, intended for families in poverty and extreme poverty across the country ${ }^{29}$. It integrates the Plano Brasil Sem Miséria (Brazil Without Poverty Plan), which focuses on Brazilians with a family income per capita below $\mathrm{R} \$$ 70 (around US\$ 30) monthly, to facilitate them in securing income, in productive inclusion and in access to public services ${ }^{30}$. Based on the definition of the population included in the social policy of PBF and the segregators' family monthly income, it was observed that part of the segregators do not meet the income requirement required by the program, despite the high prevalence of food insecurity.

Sanitation services are primary factors in the social determination of health-disease, especially the sewerage process, which does not allow water used in the household to return to nature without treatment and become a major disease vector ${ }^{23}$. Estrutural followed the same pattern, in which large areas of human occupation arise and grow haphazardly without sanitation: today, most of the families of segregators have water and 
electricity, but $46 \%$ of households are not connected to the sewage network. This data is equivalent to that found in the National Survey by Household Sampling ${ }^{27}$, where $41.7 \%$ of Brazilian households have no sewage system. This average hides important regional differences: in the midwest, for example, this percentage increases to $44.2 \%$, similar to our study.

Another disturbing factor is the presence of disease vectors such as rats and cockroaches in the homes of segregators. According to Santos ${ }^{15}$, these vectors found in areas of urban waste disposal are animals that find food and shelter in trash, that is, those are favorable conditions for their proliferation, reaching areas in the vicinity of open dumps.

\section{Final considerations}

This research sought to examine the working and living conditions of recyclable materials segregators, in order to understand the relationship between the health-disease process and their profession.

It was observed that most segregators have already had some kind of accident, and that they have some awareness of the dangers in their work environment. Associated with this, the work organization and nonuse of PPE contribute to the increased exposure to risks. Another relevant aspect is the importance of women's role in this context, because they represent the majority of segregators, take on the role of the head of the family in many cases and have more accidents. The data collected indicate that gender is an essential component to be considered in the planning of public policy interventions on the problem of open dumps.

Concerning social variables, consumption of food from the garbage and food insecurity are present in the daily life of segregators. Their living conditions are poor and do not offer all the resources needed for the representation of a decent housing. Apart from this, the presence of disease vectors in these workers' homes characterize a direct interference of the environmental impact of the open dump on the health of residents of Estrutural.

In this sense, segregators are in a vulnerable community, not solely from the perspective of the workers' health, but from the environmental aspect. Thus, given the complexity of the topic, the following questions are raised: How will the State promote the social and economic inclusion of thousands of segregators, due to their close dependence (survival) on the open dumps? With the future elimination of open dumps, how will we manage to arrange the recycling sector productively, so as to ensure dignified work for segregators? What is the impact on the workers' health and workplace after the Law no. 12.305/2010, which established the National Policy on Solid Waste? How can we make social policies more effective to this population?

This scenario raises the need for further study on this reality in order to reveal the problem and break the barriers imposed by social, economic and environmental marginalization experienced by this population. The unveiling of this reality, associated with processes of political mobilization of that social group, may contribute to changing this serious social and sanitary situation.

\section{Appendix}

Participants in the Estrutural research group: Ada dos Santos Bento; Ádria Vanessa Torres Mendes; Adriana Borges Araújo; Aimê Oliveira; Alexandre William Rolim da Silva; Ana Beatriz Oliveira Leite; Anna Carolyne Ferreira Alencar; Bárbara de Souza Pereira; Cinndy Jhessy Farias Wanzeller; Dayane Araújo Proença; Débora Cristiane Lima Barbosa; Dryele Oliveira; Edson Augusto de Lima; Eduardo de Lima Ribeiro; Ellen Mayara Souza Pires; Emery Bandeira de Almeida Junior; Esther Miguel Ottoni; Gabriela Ramos Maletzki; Grasiela de Sousa Pereira; Hélcio Carlos Barbosa; Iara Marina de Oliveira Tillmann; Jéssica Castro Diniz Cardoso; Jéssica Muniz Weber; Jéssica Raíza Vieira de Almeida; Jéssica Vasconcelos Ribeiro; João Gabriel Marques de Brito e Silva; Julia Souza; 
Juliana Santos da Silva; Jully Ane Bonfim Ataides; Larissa Mitie Fukushi; Larissa Pereira Gonçalves; Leonardo Pimenta Brito; Luana Nascimento Queiroz; Lucas Santos e Ávila; Mariana Cyncynates Gomes; Mariana Torres Máximo; Mayara Menezes de Oliveira; Natália Araújo de Oliveira; Nathália Pelanda Chen; Natasha Amin Santos; Paulo Henrique Melo da Silva; Pedro Terra Teles de Sá; Priscilla Dantas Nunes; Priscila Olin Silva; Rafael Camargo Mendes; Rafael Vieira Pimentel; Sete Nunes; Shila Minari Hargreaves; Tayne Mirela Santos Sales; Tulio César de Lima Lins; Yvana Pereira Mazzini,of Universidade de Brasília.

\section{Acknowledgments}

We would like to thank the families of Estrutural City for welcoming us; the technicians of SEDEST (State Department of
Social Development and Income Transfer) Amanda Montalvão, Monique Souza, Sônia Figueiredo and Victor Araújo; technicians Vânia Vedana, Maíra Dias and Aline Melo Nascimento; Community Health Agents Adjailton Firmino da Silva, Anderson da Silva Santos, Elias Cirqueira, Flaviane Bandeira, Francisco França da Silva, Jean da Costa, José Luis Alves, Milena Pereira, Neuza Pereira, Nilvaete Santiago, Rosa Amélia da Silva, Rosilene de Jesus, Sirlene Rodrigues, Valdonésio Claro and Vandré Barbosa, who supervised the fieldwork; all community leaders, especially Duda and Djalma Nascimento; colleagues Frederico Guanais, Denise Lopes Porto, Otaliba Libânio de Morais Neto, Antony Stevens, Juan José Cortez Escalante, Letícia Bartholo de Oliveira and Lucia Maria Modesto Pereira, for donating their fees relating to copyrights to fund this study.

\section{References}

1. Pereira MFB, Amaral AS. Lixo, segurança e saúde: conscientizando os agentes ecológicos do município de Dourados-MSa respeito de segurança do trabalho. In: Seminário de Extensão Universitária - SEMEX; 2011; Dourados (Br). Mato Grosso do Sul: Universidade Estadual de Mato Grosso do Sul; 2011. Anais eletrônicos. Disponível em: http://periodicos.uems.br/index.php/semex/article/ view/2284. (Acessado em 21 de abril de 2012).

2. Porto MFS, Juncá DCM, Gonçalves RS, Filhote MIF. Lixo, trabalho e saúde: um estudo de caso com catadores em um aterro metropolitano no Rio de Janeiro. Cad Saude Publica 2004; 20(6): 1503-14

3. Siqueira MM, Moraes MS. Saúde coletiva, resíduos sólidos urbanos e os catadores de lixo. Cien Saude Colet 2009; 14(6): 2115-22.

4. BRASIL. Lei n. ${ }^{\circ} 12.305$, de 2 de agosto de 2010. Estabelece a Política Nacional de Resíduos Sólidos. Diário Oficial da União: Brasília, DF; 2010.

5. BRASIL, Ministério do Planejamento, Orçamento e Gestão. Instituto Brasileiro de Geografia e Estatística - IBGE. Pesquisa Nacional de Saneamento Básico 2008. Rio de Janeiro: IBGE; 2010

6. Alexandrino DFL, Ferreira MEC, Lima CL, Makkai LFC. Proposta de inclusão social e melhoria da qualidade de vida e saúde dos catadores e catadoras de materiais recicláveis de Viçosa - MG através da atividade física. Fit Perf J 2009; 8(2): 115-22.
7. Maciel RH, Matos TGR, Borsoi ICF, Mendes ABC, Siebra PT, Mota CA. Precariedade do trabalho e da vida de catadores de recicláveis em Fortaleza, CE. Arq Bras Psicol 2011; 63 (Suppl): 71-82.

8. Lermen HS,Fisher PD. Percepção ambiental como fator de saúde pública em área de vulnerabilidade social no Brasil. Rev APS 2010; 13(1): 62-71.

9. Almeida JR, Elias ET, Magalhães MA, Vieira AJ. Efeito da idade sobre a qualidade de vida e saúde dos catadores de materiais recicláveis de uma associação em Governador Valadares, Minas Gerais, Brasil. Cien Saude Colet 2009; 14(6): 2169-80.

10. Brasil. Ministério do Trabalho e Emprego. Portaria n. 3214, de 8 de junho de 1978. Publica o texto-base das Normas Regulamentadoras relativas a segurança e medicina do trabalho. Brasília: Diário Oficial da República Federativa do Brasil; 1978.

11. Brasil. Ministério da Saúde. Portaria Interministerial $\mathrm{n}$. 800, de 3 de maio de 2005. Publica o texto-base da minuta de Política Nacional de Segurança e saúde do trabalhador. Brasília: Diário Oficial da União; 2005.

12. Brasil. Ministério da Saúde. Notificação de Acidentes do Trabalho: fatais, graves e com crianças e adolescentes. Saúde do trabalhador - protocolos de complexidade diferenciada. Série A. Normas e Manuais Técnicos. Brasília: Ministério da Saúde; 2006. 
13. Cavalcante S, Franco MFA. Profissão perigo: percepção de risco à saúde entre catadores do lixão do Jangurussu. Revista Mal-estar e Subjetividade 2007; 7(1): 211-31.

14. Puech MPSR. Grupo de catadores autônomos na coleta seletiva no município de São Paulo [dissertação de mestrado]. São Paulo: Faculdade de Saúde Pública da USP; 2008.

15. Santos GO. Interfaces do lixo com o trabalho, a saúde e o ambiente - artigo de revisão. Revista Saúde e Ambiente 2009; 10(2): 26-35.

16. Machado ER, Teixeira EM, Paula FM, Gonçalves-Pires MRF, Ueta MT, Costa-Cruz JM. Immunoparasitological diagnosis of Strongyloides stercoralis in garbage collectors in Uberlândia, MG, Brazil. Parasitol Latinoam 2007; 62: $180-2$

17. Vidal J. Políticas públicas e (in)justiça ambiental: o caso da Vila Estrutural. Web artigos 2009. Disponível em: http:// www.webartigos.com/artigos/politicas-publicas-e-injustica-ambietal-o-caso-da-vila-estrututal/27707. (Acessado em 24 de abril de 2012).

18. Paiva JM. Direito à cidade no Distrito Federal - inclusão e exclusão de famílias de baixa renda - o caso da Vila Estrutural [monografia de Bacharelado em Serviço Social]. Brasília: Universidade de Brasília; 2007.

19. Santos JV, Gigante DP, Domingues MR. Prevalência de insegurança alimentar em Pelotas, Rio Grande do Sul, Brasil, e estado nutricional de indivíduos que vivem nessa condição. Cad Saude Publica 2010; 26(1): 41-9.

20. Fórum de Monitoramento Social da Cidade Estrutural. Reunião da rede socioassistencial da Estrutural. Disponivel em: http://forumestrutural.blogspot.com/>. Acessado em 20 de abril de 2012).

21. Brasil. Senado Federal. Constituição da República Federativa do Brasil de 1988: Capítulo II - Dos Direitos Sociais. Brasília, DF; 1988.

22. Brasil. Presidência da Republica. Decreto-lei n. 5.452 de 01 de maio de1943. Aprova a Consolidação das Leis do Trabalho. Brasília: Diário Oficial da União; 1943.
23. Brasil. Ministério do Planejamento, Orçamento e Gestão. Instituto Brasileiro de Geografia e Estatística - IBGE. Síntese de Indicadores Sociais- uma análise das condições de vida da população brasileira. Rio de Janeiro: IBGE; 2010.

24. Tavares IAF. Do lixo à reciclagem: uma visão sobre o trabalho dos catadores no município de Divinópolis [dissertação de mestrado]. Minas Gerais: Mestrado em Educação, Cultura e Organizações Sociais, Universidade Estadual de Minas Gerais; 2008.

25. Vacari DA. Condições de trabalho de catadores de materiais recicláveis na região do Guarituba. In: XVII Congresso brasileiro de Ciência do Esporte e IV Congresso Internacional de Ciência do Esporte; 2011; Porto Alegre (Br). Rio Grande do Sul. 2011. Anais eletrônicos. Disponível em: www.rbceonline.org.br/congressos/index. php/XVII_CONBRACE/2011/paper/viewFile/3241/1749. (Acessado em 21 de abril de 2012).

26. Ribeiro H, Besen GR. Panorama da coleta seletiva no brasil: desafios e perspectivas a partir de três estudos de caso. INTERFACEHS - Revista de Gestão Integrada em Saúde do Trabalho e Meio Ambiente 2007; 2(4): 1-18.

27. Dall'Agnol CM, Fernandes FS. Saúde e autocuidado entre catadores de lixo: vivências no trabalho em uma cooperativa de lixo reciclável. Rev Latino-am Enfermagem 2007; 15(spe.): 729-35.

28. Alencar MCB, Cardoso CCO, Antunes MC. Condições de trabalho e sintomas relacionados à saúde de catadores de materiais recicláveis em Curitiba. Rev Ter Ocup USP 2009; 20(1): 36-42.

29. Silva MOS. O Bolsa Família: problematizando questões centrais na política de transferência de renda no Brasil. Cien Saude Coletiva 2007; 12(6): 1429-39.

30. Brasil. Ministério do Desenvolvimento Social e Combate à Fome. Programa Bolsa Família. Disponivel em: http://www. mds.gov.br/bolsafamilia. (Acessado em 28 de abril de 2012).

Received on: 05/03/12

Final version presented on: 09/28/12

Accepted on: 04/08/13 